duction of flavour in bacon and ham (Food Investigation Special Report No. 49. "The Function of Nitrate, Nitrite, and Bacteria in the Curing of Bacon and Ham". H.M. Stationery Office. 9d. net). Curing of pork for bacon and ham was originally a process of dry salting. Now, the pickle used is liquid, and the process is supplemented by injecting the pickle into the tissues of the carcass. The traditional pickling materials - salt and saltpetre-are still used in Great Britain, but it has long been known that the 'cured colour' is due to the formation of nitrite by the action of bacteria upon the saltpetre. The nitrite formed reacts with the blood colouring matter present to form a special pigment, nitroso-hæmoglobin. It is shown that a satisfactory English bacon can be made by using only sodium chloride and sodium nitrite in the pickle, and that bacteria and nitrate are not essential for the development of the flavour. A very small content of free nitrite, as low as ten parts per million in the final product, is sufficient to produce a satisfactory flavour and colour. The report indicates the possibility of recasting the present practice so as to give the curer better control over the quality of this product.

\section{The Stoic}

THE April number of the Stoic represents, not the "famed Athenian Porch", but Stowe School, which, starting at one of the great houses which flourished in the eighteenth century, has long since won its way to recognition on a par with older foundations. The school magazine is one of the best we have seen, including literary matter as well as the usual records of activities. Stowe is now responsible for two London clubs for boys. It produces its own films, which have dealt with several classes of animals and plant-life, while the Natural History Society, started last year, keeps a journal of work done which is well spoken of. The school evidently enjoys many things besides the normal curriculum. The illustrations make a good show and include a lively "Decorated Black-out Screen" designed by a young artist.

\section{Earthquakes in the United States and in Italy}

ON Saturday and Sunday, May 18 and 19, severe earthquake shocks were experienced in the southwestern United States and in Italy. In the United States eleven shocks were felt at places so far apart as 800 miles in Southern California and Arizona. The town of Imperial is reported in ruins, with five people killed and many injured. Owing to the disruption of communications, further details are not yet available. The place most affected in Italy appears to have been San Servo.

\section{Other Recent Earthquakes}

REPORTS from the seismological observatories at Kew (England) and De Bilt (Holland) confirm that there were two large earthquakes on May 4 and one on May 5. At Kew the first commenced recording at $7 \mathrm{~h} .35 \mathrm{~m}$. 55s. G.M.T. on May 4, and the epicentre was estimated to be distant $8,500 \mathrm{~km}$. The second was received at Kew at $21 \mathrm{~h}$. $10 \mathrm{~m}$. 7s. G.M.T. on the same day, with an estimated epicentral distance of $4,770 \mathrm{~km}$., and gave rise to ground amplitudes of $54 \mu$. The third commenced recording at $2 \mathrm{~h} .16 \mathrm{~m}$. 40s. G.M.T. on May 5 at Kew, and the estimated epicentral distance was $9,750 \mathrm{~km}$. These readings have been confirmed by equivalent readings from De Bilt. Dr. G. van Dyk is of the opinion that the first on May 4 originated near the Aleutian Islands, which has recently been observed to be seismically active (NATURE, May 4, p. 701 and earlier issues) and that the second on May 4 may have come from an easterly azimuth.

\section{The Night Sky in June}

THE nights around the summer solstice on June 21 are shorter than $7 \frac{1}{2}$ hours in the latitude of London, reckoned from sunset to sunrise; excluding twilight (nautical) darkness lasts only about three hours. The moon is new on June 6 and full on June 19. Venus, which is still a brilliant evening star at the beginning of the month, draws rapidly towards the sun's place and is at inferior conjunction on June 26. Mercury is also an evening star in conjunction with Venus on June 12 and with Mars on June 17 ; on June 24 Mercury is at greatest elongation (25 east). Mars is getting less easy to see; it is close to Venus on June 7. Jupiter and Saturn are both morning stars, the former rising soon after $1 \mathrm{~h}$. $30 \mathrm{~m}$. U.T. on June 16 , followed $\frac{1}{4} \mathrm{hr}$. later by Saturn. At dusk in midJune, the red star Antares is about south. Areturus has already southed, while Vega is some, 3 hours before the meridian. The constellations, Bootes, Hercules and Ophiuchus contain some interesting double stars of which $\varepsilon$ Boötis $\left(2 \cdot 8^{\prime \prime}\right)$, $\xi$ Bootis $\left(5 \cdot 1^{\prime \prime}\right)$, $\alpha$ Herculis $\left(4 \cdot 8^{\prime \prime}\right)$ and 70 Ophiuchi $\left(6 \cdot 6^{\prime \prime}\right)$ are good examples. Between $\eta$ and $\zeta$ Herculis may be glimpsed with the naked eye under favourable conditions the great star cluster, $M 13$, the distance of which is of the order 35,000 light years. The outer part of the cluster can be resolved into stars with a $2 \frac{1}{2}$ - or 3 -inch refractor. The Scorpiid meteors are at their greatest frequency about June 4, their radiant point being north, following Antares.

\section{Announcements}

The Editors of NATURE have decided that, for the time being, the receipt of the manuscript of contributions cannot be acknowledged. Furthermore, it is found essential to reduce the number of proofs sent to the author of contributions submitted to one. This proof must be accepted as an acknowledgement of receipt of the copy.

Among his personal assistants, the Prime Minister has appointed Prof. F. A. Lindemann, F.R.S., professor of experimental philosophy in the University of Oxford, for advice concerning statistics and research.

Dr. H. SHAw, keeper in the Department of Physics and Geophysics at the Science Museum, has been appointed acting director of the Museum during the absence of Brigadier E. E. B. Mackintosh. 